\title{
ASSESSING THE EFFECTS OF THE MFA/ATC FROM US AND WORLD TRADE DATA AFTER ITS REMOVAL
}

\author{
Daqing Yao \\ John Whalley \\ Working Paper 21299 \\ http://www.nber.org/papers/w21299 \\ NATIONAL BUREAU OF ECONOMIC RESEARCH \\ 1050 Massachusetts Avenue \\ Cambridge, MA 02138 \\ June 2015
}

We are grateful to the ORF (Ontario Research Fund) and CIGI (Centre for International Governance Innovation) for financial support. The views expressed herein are those of the authors and do not necessarily reflect the views of the National Bureau of Economic Research.

NBER working papers are circulated for discussion and comment purposes. They have not been peerreviewed or been subject to the review by the NBER Board of Directors that accompanies official NBER publications.

(C) 2015 by Daqing Yao and John Whalley. All rights reserved. Short sections of text, not to exceed two paragraphs, may be quoted without explicit permission provided that full credit, including $₫$ notice, is given to the source. 
Assessing the Effects of the MFA/ATC from US and World Trade Data after Its Removal Daqing Yao and John Whalley

NBER Working Paper No. 21299

June 2015

JEL No. F13,F14,F68

\section{$\underline{\text { ABSTRACT }}$}

In this paper we assess the effects of the MFA/ATC using both world trade and US data after its removal. Previous literature assesses its effects while in operation. The trade data we analyze are consistent with theoretical predictions of more trade volumes, lower product prices, smaller effect of RTA on trade, less transshipment and quota hopping investment, and higher country concentration of exporters. We also find the effects of the MFA on clothing trade were more significant than for textiles trade. The benefits from freer trade in textiles and clothing shed light on other sectors that are still under trade protection.

Daqing Yao

Institute of World Economy

Shanghai Academy of Social Sciences

622 Huaihaizhong Rd.

Shanghai, 200020

China, P.R.

yaodaqing@sass.org.cn

John Whalley

Department of Economics

Social Science Centre

University of Western Ontario

London, ON N6A 5C2

CANADA

and NBER

jwhalley@uwo.ca 


\section{Introduction and Background}

During its 20 years of operation, and following the earlier Short and Long Term Agreements on Cotton Textiles, the Multi Fiber Agreement (MFA) was the subject of study by many trade economists (Evans and Harrigan, 2005; Rotunno, 2013; Dayaratna and Whalley, 2007; Khandelwal, Schott and Wei, 2013; etc.). Although terminated in 2005 under the WTO Agreement on Textile and Clothing (ATC), its effects lingered for some years, in part through Transitional Safeguards Arrangements with China (and others). As a system of quota restrictions on the growth rate of trade its effects as a global system of trade restrictions bear study given the prevalence of other remaining quota restrictions worldwide, most notably in agricultural products such as cheese and sugar.

The list of the effects of the MFA include reduced volumes of trade, higher prices for restricted products, quality upgrading, trans-shipment to avoid quota, quota hopping foreign investment, internal quota allocation schemes, and others. In contrast to analyses of these effects generated from data when the MFA was in operation, here we attempt to use data after the 2005 termination of the MFA instead to gauge these effects as they are progressively removed. How clearly identifiable are they in available data? How strong are the various effects? How long is the adjustment period to a MFA free world for each of them? 
In this paper, we use both world and U.S. trade data generated after the termination of the Multi Fiber Agreement (MFA) to access its effects. Textiles and Clothing was a special sector in world trade in the age of the General Agreement on Tariffs and Trade (GATT), since trade in this sector was governed by the Multi Fiber Agreement (MFA). From 1974 onwards the MFA allowed for quotas restrictions on growth rates of trade in cotton, wool and man-made fibers. By the end of the second MFA (1981), most exports from developing countries to the United States and the EU countries were covered by bilateral quota agreements restraining the growth rate of trade. These violated the spirit of the nondiscrimination principle in the GATT multilateral system, but the MFA was renegotiated four times and finally expired at the end of 1994. Six developed countries applied quotas during the final year of the MFA (1994): the EU, Austria, Canada, Finland, Norway and the United States ${ }^{1}$.

The MFA quota system did not end with the expiration of the MFA. From January 1, 1995 on when the WTO began, there was a ten year transitional period under the Agreement on Textiles and Clothing (ATC). Four countries continued with MFA quota restrictions in the ATC: Canada, the EU, Norway and the United States, until January 1, 2005 from when onwards textiles and clothing trade has been under the general rules of the WTO.

The reason for such special treatment in the WTO is in that the textiles and clothing

1 Austria and Finland joined the EU in January 1, 1995, but in 1994 they were not EU members. 
sector is important not only for developing countries, but also for developed countries. In the European Union, for example, the textiles and clothing sector is dominated by small and medium-sized enterprises concentrated in a number of regions that are highly dependent on the sector. (Nordas, 2004) The US textile manufacturers produce yarn, thread, and fabric for apparel, home furnishings, and various industrial applications. In 2013, the U.S. textile industry generated nearly $\$ 57$ billion in shipments and directly employed about 230,700 workers, accounting for approximately $2 \%$ of all US factory jobs $^{2}$. To the developing countries, the textiles and clothing industry offers industrialization and jobs for unskilled workers, including women who previously have no other income opportunities. Many emerging economics have taken this sector as their first step to industrialization, including Korea, China, and Viet Nam.

Now ten years after 2005, we can access both the extent and speed of transition to a quota free regime in world textiles and clothing trade. Our main findings are: 1) since 2005 the trade volume in clothing and textiles has increased more quickly than the average for all world trade. This is consistent with expectations following the removal of quota restrictions. The increase in world clothing trade is greater than that of world textiles trade. 2) The average price of both clothing and textiles is lower after the quota system expired, again consistent with expectations to the removal of quotas. 3) The average quality of exports of clothing has fallen, as consumers were quality upgrading under the MFA. 4) The concentration by country of world textiles and clothing exports

\footnotetext{
2 Platzer (2014), p.1
} 
has increased, consistent with the removal of MFA quota hopping foreign investment.

5) The concentration by country of world imports has changed relatively little, as quota hopping only affects the export side of trade. 6) The concentration indices of clothing have increased significantly, while those of textiles remains relatively stable. 7) The regional textiles and clothing trade of RTA members is smaller, since world trade in textiles and clothing is freer. 8) clothing trade has been affected more by the removal of the MFA quota system than textiles trade.

\section{Literature and theory analysis on the effects of the MFA}

Essentially the MFA/ATC is a quota system, based on restrictions on the growth rates of exports in textiles and clothing sector. It represents a quantity restriction on trade and from basic economic theory we can hypothesizes the following effects of the MFA.

2a) Reduced Volume of Trade

The first direct effect of MFA quota system is reduced trade volume. Evans and Harrigan (2005) use the term "fill rate" to indicate the restrictiveness of quota, where fill rate is defined as the percentage of a quota that is used. Higher fill rates indicate that the quota keeps imports below what they would otherwise be. A quota with a fill rate of 90 percent or above is defined by them as a binding quota. Evans and Harrigan (2005) find that about 40 percent of US apparel imports came in under binding quotas 
throughout the 1990s.

2b) Higher Price for Restricted Products

With the trade volume reduced, restricted products will have a higher price in import markets. Such a higher price is caused by two factors. One is the exporters who can get the quota will send higher priced products to export to make full use of the scarce quota. The other is the limited supply in the importing country which will also lead to a higher market price. Evans and Harrigan (2005) find that the effect of quotas on prices is a step function: for fill rates between zero and 90 percent, the effect is zero, and for fill rates above 90 the effect is present.

\section{2c) Quality Upgrading}

A third effect is quality upgrading. When quotas are set in physical rather than volume terms, exporters will export higher priced higher quality items. Feenstra (2004) provides a theoretical frame for measuring quality upgrading due to quotas. There are two causes for such quality upgrading. One is when facing quota restriction the foreign

firms will export those products that have higher quality. The other is the so called "Washington apples" effect, which means the highest quality product will have the smallest relative increase in quality-adjusted price when the quota is binding. 
2d) Transshipment to Avoid Quota

In order to avoid quota restrictions, some MFA exporters used the strategy of transshipment, which means export to a third country which is less restricted by quota, and then re-export to the final destination for import markets. Such pattern changes can be seen in the experience of the African Growth and Opportunity Act (AGOA) countries, which is clearly analyzed in Rotunno (2013).

2e) Quota hopping Foreign Investment

Another strategy to avoid quota restrictions is quota hopping foreign investment, which implies investment in a third country less restricted by the quota where production of the final product takes place and then reexport to the destination market. Dayaratna and Whalley (2007) argue that there were "China containment agreements" in the post-MFA regime until 2013, which were trade restrictions primarily targeted at China. The quota restriction of China's textile and clothing export which impeded the growth of Chinese exports, benefited other developing countries such as Viet Nam, and brought quotahopping investment by China.

2f) Internal Quota Allocation Schemes

The last effect of quotas we focus on is induced internal quota allocation schemes in 
the exporting country, which including auction of export licenses, government assignment of quota, and other rent seeking features. Trela and Whalley (1995) suggest that schemes used within developing countries to allocate textile export quota among domestic producers typically have more severe negative effects on developing country economic performance than the MFA export quotas themselves. Quotas were typically allocated to established rather than new and more efficient producers. These quotaallocation schemes amplify the welfare loss caused by the quota. A later paper, Khandelwal, Schott and Wei (2013) draw similar results by examining Chinese textile and clothing exports before and after the elimination of externally imposed export quotas.

\section{Assessing the Effects of the MFA from US and World Trade Data}

We use world trade data and US trade data to assess the effects of the MFA. Some effects can be found by in world trade data; for example the concentration patterns change in exporters, but some other effects cannot easily be seen at such an aggregate level. For example if we want to analysis the product quality change, we will need the price data, which is not available in UN's Comtrade Database. Therefore we must turn to country level trade data. Although the EU and Canada statistics also provide some trade data in textiles and clothing sector, they are not detailed enough or too limit in time length to be used here. The only detailed trade data available in country level is from US's Office of Textiles and Apparel 
(OTEXA), therefore we use it wherever the world data is not enough for analysis.

\section{3a) Overall Trends}

Since 2001 the world trade volume of textiles and clothing has increased steadily. As shown in Fig.1, in 2001 the world import value of textiles was 144.8 billion US\$, while in 2013 this has increased to 242.1 billion, with an average increase rate of $4.4 \%$. The trade of clothing is larger and increase quicker than textiles trade. In 2001 the trade volume of clothing was 215.9 billion US\$, and in 2013 this has nearly doubled to 404.8 billion US\$, with an average increase rate of 5.4\%. During the same period, the world total import value of goods and services has increased from 9.82 trillion to 17.6 trillion (constant 2005 US\$), with an average increase rate of $4.9 \%$.

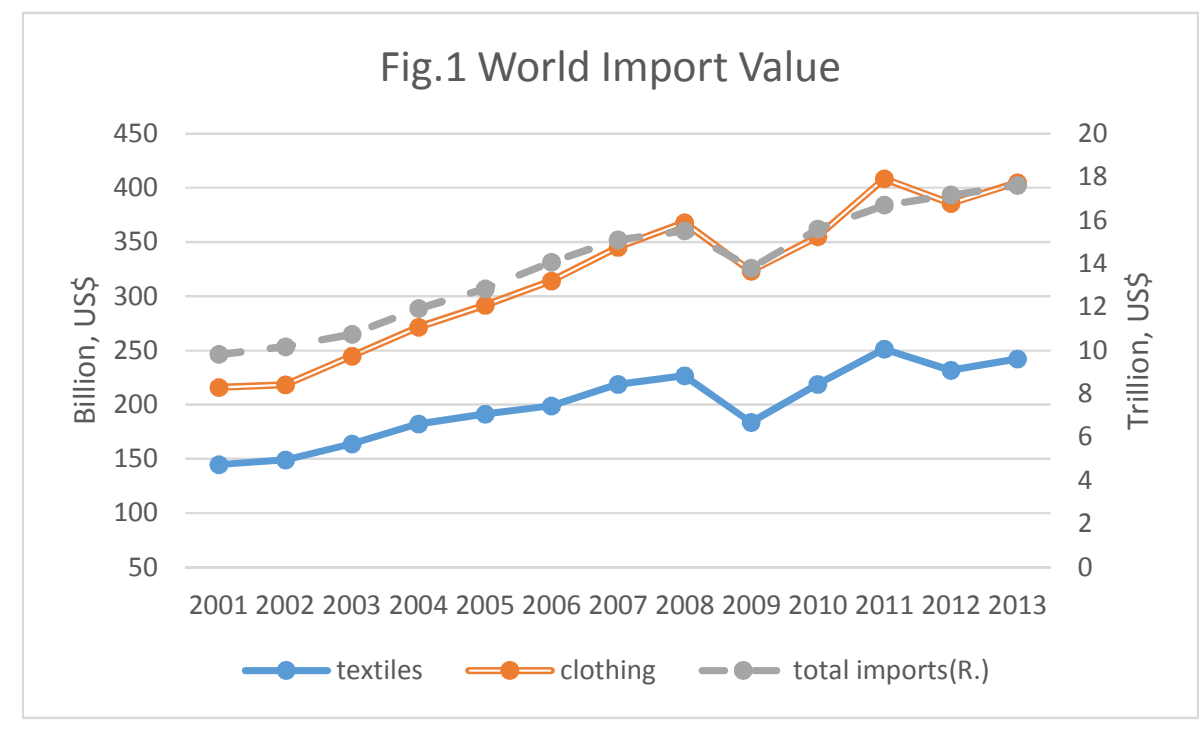

Source: UN's Comtrade Database and World Bank’s WDI Database 
There are two times when trade decreased during this period. The first time is in 2009, when the world economy and trade fell sharply after the global financial crisis. The world import of textiles decreased $12.2 \%$ and import of clothing decreased $19.0 \%$ from 2008. The second time is in 2012, with the economic contraction and Euro crisis in the EU. This time the decrease is $5.6 \%$ in textiles and $7.7 \%$ in clothing. The two series of textiles and clothing trade show similarity in their trends, because they are in the same industry.

We then analysis the imports of textiles and clothing by the United States, the biggest import country in the world. The pattern of higher growth of imports after 2005 is connected with the removal of the MFA. From Fig.2 we can see that the U.S. imports more clothing than textiles, with the former about four to five times larger than the latter. Clothing imports increase more quickly than textile imports in the period 2001 to 2013; the rate of clothing import increase is 5\%, while the rate of textiles import increase is $2.5 \%$. This is consistent with the removal of the MFA. The variation in the rate of increase is larger in the clothing sector than in textiles. In 2009 when the global financial crisis moved the US economy into recession, imports of clothing dropped to 72 billion US\$ from the previous year's 82 billion. After one year clothing imports recovered to 81 billion, and in 2011 increased to 88 billion US\$. Imports of textiles were relatively stable, increasing from 19 to 27 billion US\$ after 2004. 


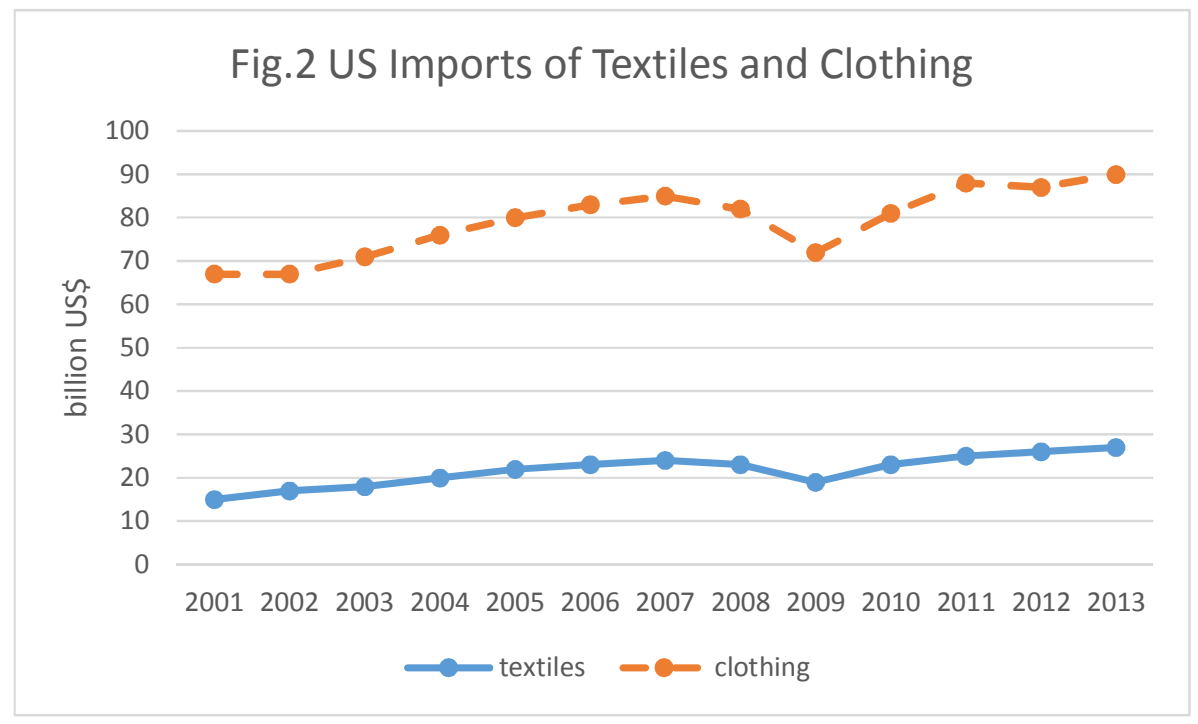

Source: UN's Comtrade Database

3b) Higher Prices and Quality Upgrading for Protected Products

From trade theory the average price of United States' imports would tend to decrease after the end of the MFA/AFC quota system. This is also in accordance with the data. We can see in Fig. 3 that the average price of US imports kept dropping after 2001, and the import price from China fell sharply in 2002. As a comparison, the import price from Viet Nam jumped up at the same period. Facing competition from China, other exporters move up the price ladder. If price is a good proxy for quality, one can also say that the average quality of US textile and clothing imports is lower since the end of MFA/AFC quota system. 


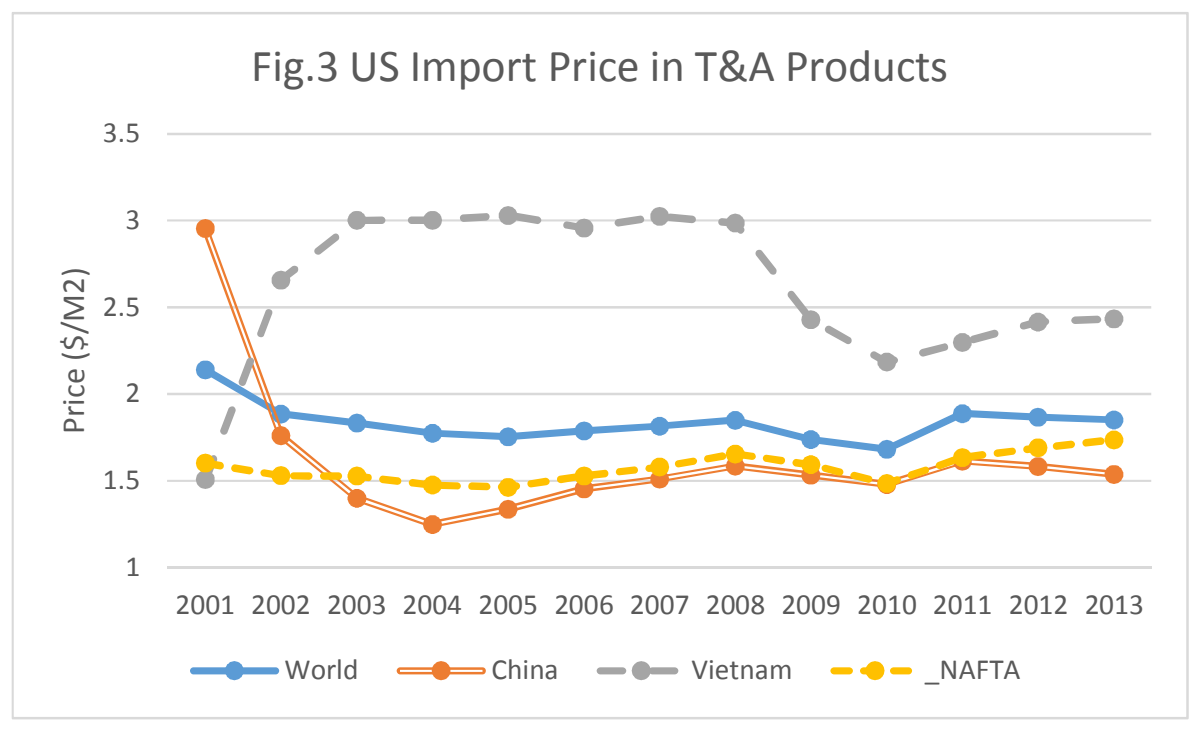

Source: data from http://otexa.trade.gov/Msrcat.htm

Considering the import quantity makes the pattern of change clearer. As Fig.4 shows, the import quantity of the US from China kept increasing between 2001 and 2004, which is an outcome of a higher quota cap. After 2005 the rate of increase is higher, except during the 2008 global crisis. Viet Nam did not join the WTO system in this period, therefore its export quantity did not increase much. Facing competition from China, Viet Nam had to move into the higher ladder of product quality, and its export price increased significantly. After 2005, the import quantity from NAFTA dropped quickly. 


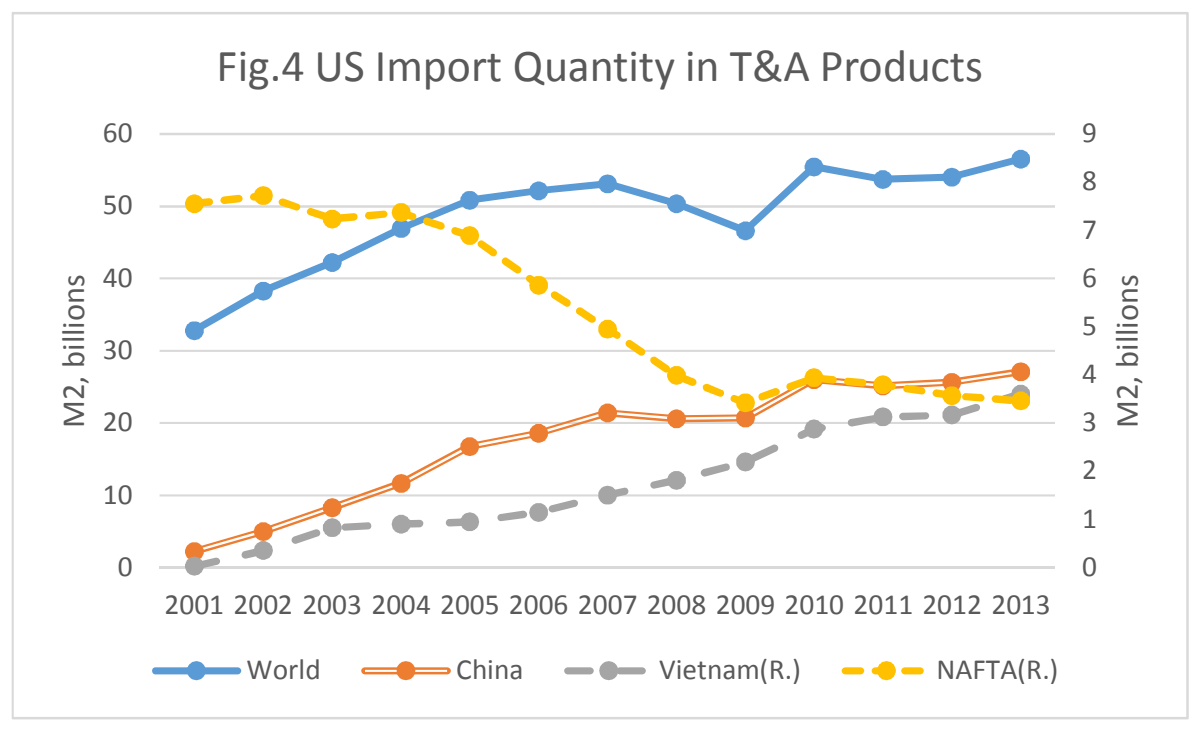

Source: data from http://otexa.trade.gov/Msrcat.htm

3c) Transshipment and Quota Hopping Foreign Investment

Another change following the expiration of the MFA quota system is the end of quota-hopping investment and transshipment in textile and clothing trade. Such changes can be seen clearly in the experience of the African Growth and Opportunity Act (AGOA) countries.

Began in 2001, the AGOA enabled some less developed African countries to export hundreds of apparel products quota-free and duty-free to the United States. Although the AGOA trade preferences had a positive and significant impact on African apparel exports to the US, they did not survive the demise of the MFA/ATC quota system in 2005, and since then China has taken over the US market. 
As pointed out by Rotunno (2013), a key feature of the AGOA preference was the absence of rules of origin (ROOs), which are usually imposed under regional trade agreements to avoid transshipment. Therefore the easiest way for these underdeveloped countries to export to the US is to import directly from other countries and transship them. In Fig.5 we analyze the nine countries which started AGOA apparel exports before the end of 2002, Botswana, Ethiopia, Kenya, Malawi, Mauritius, Namibia, South Africa, Uganda and Tanzania. The increase in their exports to the US between 2003 and 2005 was accompanied by an increase of imports from China. After 2005 their exports to the US kept decreasing until 2009, and so was their import from China. We can speculate that some of their apparel import from China was transshipped to the US during the last years of MFA/ATC quota system, when these AGOA countries were free from quota restriction to export to the US.

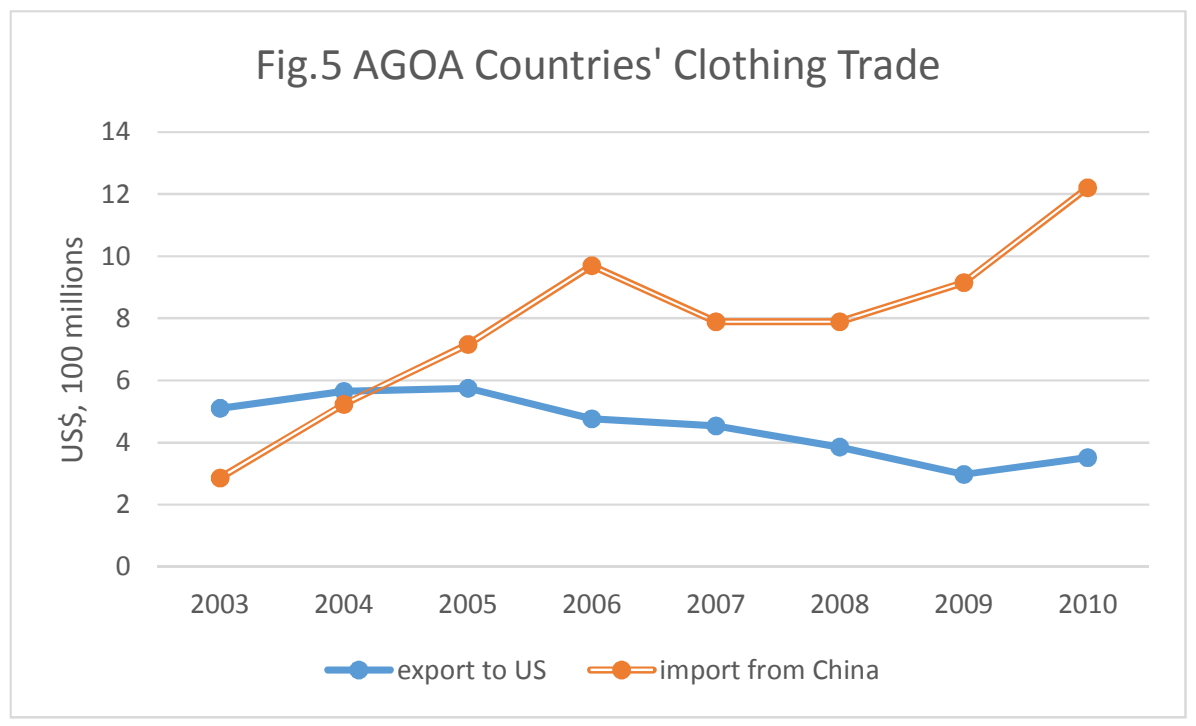

Source: UN's Comtrade Database 
Such a pattern change is more significant in individual countries, for example Botswana, Namibia and Uganda. As in Fig.6, their export to the US jumped significantly when they entered the AGOA, but fall sharply following the expiration of the MFA quota system in 2005. Since a country's industry structure and export ability cannot fluctuate so dramatically, a reasonable explanation for this pattern change is that these countries largely transshipped other countries' exports to the US.

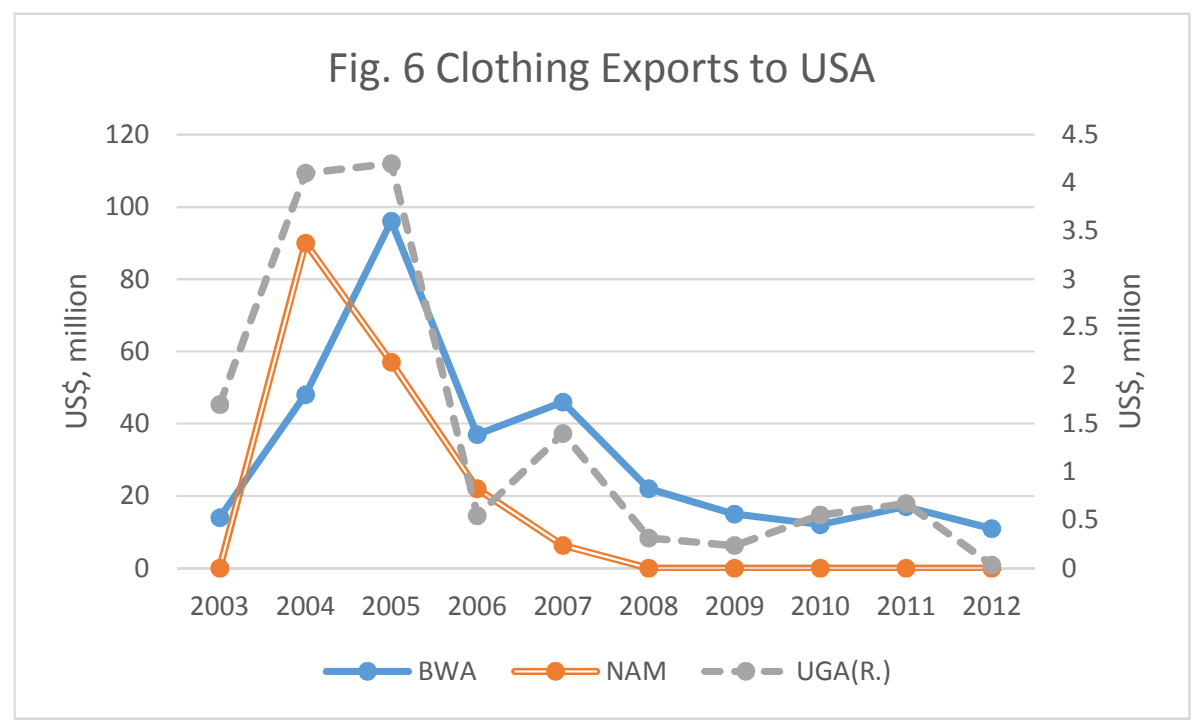

Source: UN's Comtrade Database

3d) The Textile and Clothing Trade of RTA Members is Smaller

Before the end of the MFA/AFC quota system in 2005, there were many RTAs which provide bilateral tariff reduction or quota-free access in the textile and clothing sector. An example is the NAFTA rules, under which Mexico could access 
the US market more easily, while Chinese exporters were restricted by quota. After the end of the quota system, Mexico has no preferential advantage to China, and its clothing export to the US dropped quickly.

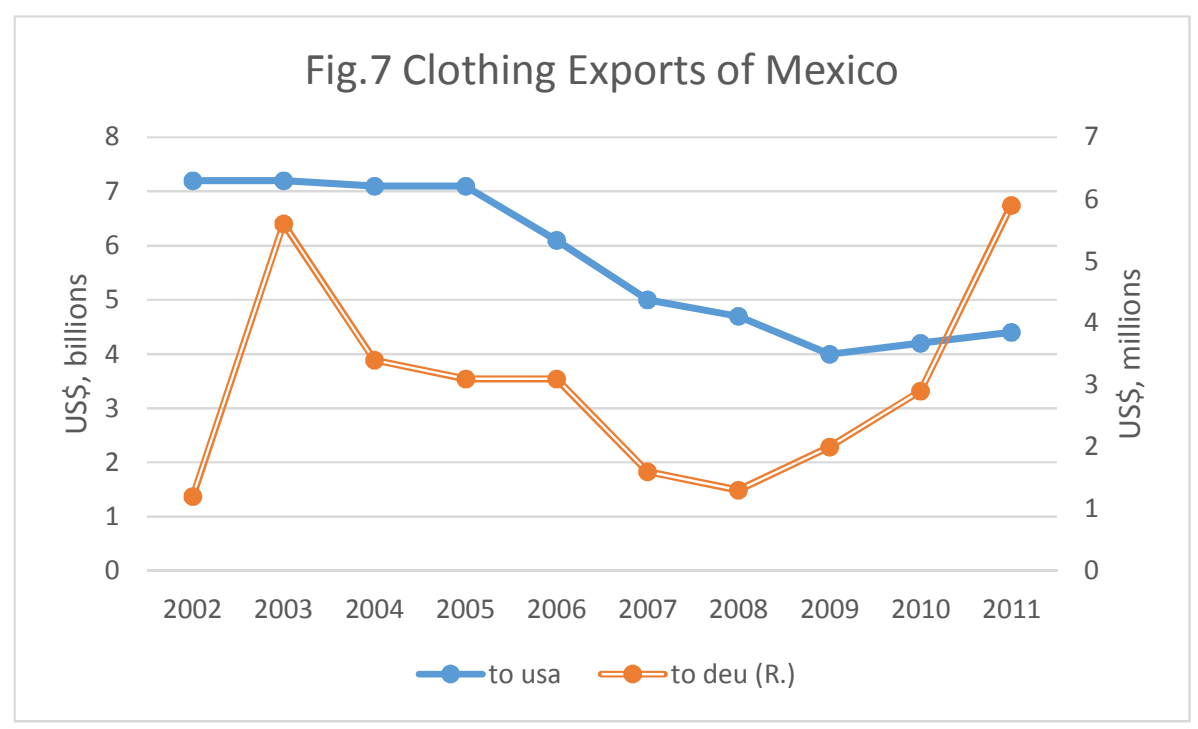

Source: UN's Comtrade Database

From Fig.7 we can see that, Mexico's clothing export to the US decreased rapidly after 2005, and were only stable after 2009 at a relative low level. In comparison, Mexico's clothing exports to Germany, where it did not have a preferential RTA during the MFA/AFC quota system, do not show such a clear decrease.

The Geographic Patterns of US imports show a similar change. Although a detailed analysis on the change of the top 20 exporters in the thirteen years will be illuminating on the geographic patterns, but this will make the table too large to place here. We only report the change of top 5 exporters in five selected years, as in 
Table 1 . We can see clearly that China is the biggest beneficial country, with her proportion increased from $13 \%$ to about $40 \%$ in both sectors. Asian exporters moved up, for example in 2013 India was the second largest exporter in textiles, and Viet Nam was the second largest in clothing export. Canada and Mexico, which are beneficiary from the NAFTA regional trade agreement, are moving down in the ladders.

Table 1: Top 5 exporters to the U.S. and shares in selected years

\begin{tabular}{|c|c|c|c|c|c|c|c|c|c|c|c|}
\hline Sector & No & 2001 & & 2004 & & 2007 & & 2010 & & 2013 & \\
\hline \multirow{5}{*}{ 氖 } & 1 & $\mathrm{CHN}$ & $13 \%$ & $\mathrm{CHN}$ & $23 \%$ & $\mathrm{CHN}$ & $32 \%$ & $\mathrm{CHN}$ & $37 \%$ & $\mathrm{CHN}$ & $37 \%$ \\
\hline & 2 & CAN & $13 \%$ & CAN & $10 \%$ & IND & $10 \%$ & IND & $11 \%$ & IND & $13 \%$ \\
\hline & 3 & MEX & $10 \%$ & IND & $9 \%$ & CAN & $8 \%$ & MEX & $7 \%$ & MEX & $6 \%$ \\
\hline & 4 & IND & $7 \%$ & MEX & $9 \%$ & MEX & $8 \%$ & PAK & $7 \%$ & PAK & $6 \%$ \\
\hline & 5 & PAK & $7 \%$ & PAK & $7 \%$ & PAK & $7 \%$ & CAN & $7 \%$ & CAN & $6 \%$ \\
\hline \multirow{5}{*}{ 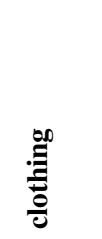 } & 1 & $\mathrm{CHN}$ & $13 \%$ & $\mathrm{CHN}$ & $18 \%$ & $\mathrm{CHN}$ & $33 \%$ & $\mathrm{CHN}$ & $41 \%$ & $\mathrm{CHN}$ & $39 \%$ \\
\hline & 2 & MEX & $12 \%$ & MEX & $9 \%$ & MEX & $6 \%$ & VNM & $8 \%$ & VNM & $10 \%$ \\
\hline & 3 & $\mathrm{HKG}$ & $7 \%$ & HKG & $5 \%$ & VNM & $5 \%$ & IDN & $6 \%$ & IDN & $6 \%$ \\
\hline & 4 & KOR & $4 \%$ & HND & $4 \%$ & IDN & $5 \%$ & BGD & $5 \%$ & BGD & $6 \%$ \\
\hline & 5 & IDN & $4 \%$ & VNM & $4 \%$ & IND & $4 \%$ & MEX & $5 \%$ & MEX & $4 \%$ \\
\hline
\end{tabular}

Source: Authors' computation based on UN's Comtrade Database

In order to give a clearer picture of the geographic patterns, we add up the export value of American exporters and Asia exporters respectively, and compute the Geographic Index ${ }^{3}$ of these two areas. We only consider these exporters that belong to the top 10 exporters, and report the results in Fig.8. In both textiles and clothing sectors the share of American exporters keep decreasing, while the share of Asian

\footnotetext{
3 The Geographic Index is defined as the share of the value of an area's exporters in the US's total imports.
} 
exporters rise rapidly. The increasing of Asian exporters' share is more relevant to the quota expiration in 2005 .

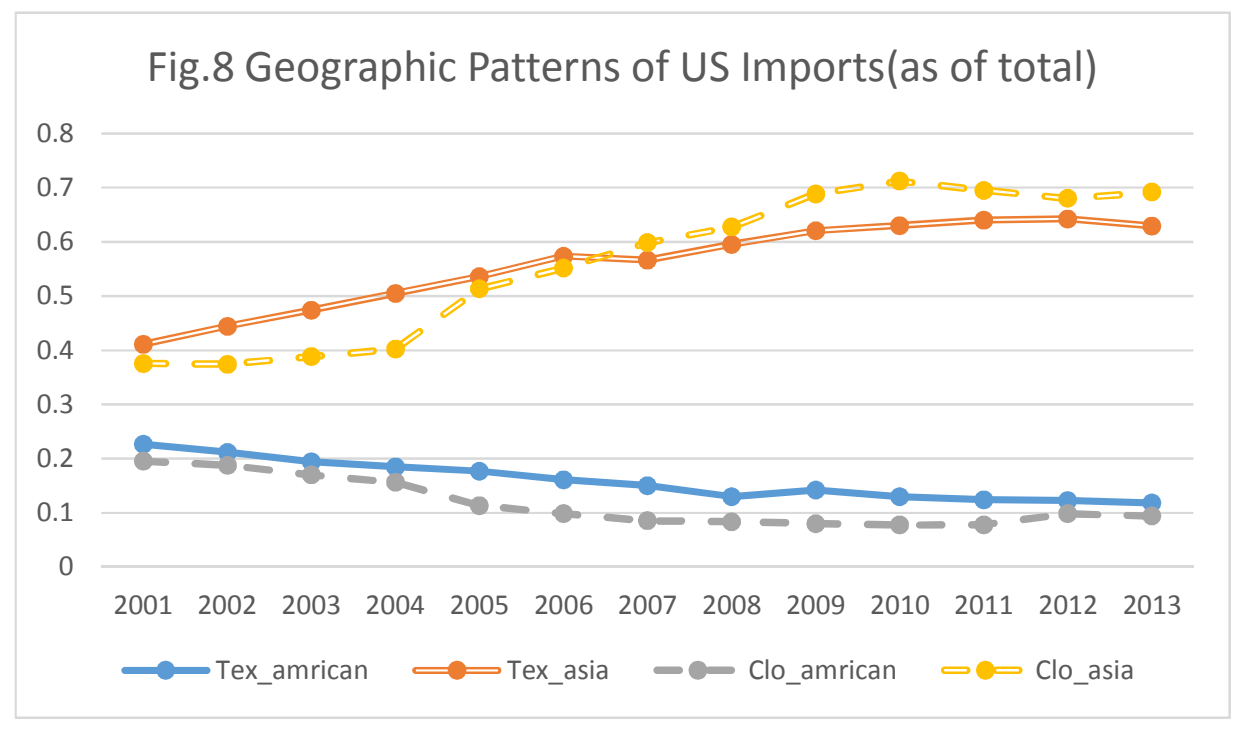

Source: Authors' computation based on UN's Comtrade Database

3e) Concentration by country of world imports

Now we turn to analysis the concentration pattern of world textiles and clothing trade. In this and the following section we use the data of the world, instead of the US trade data, since the US itself is one of the most important traders in the world and an analysis omitting US will be meaningless.

The top 10 importers of textiles have changed significantly since 2001. As shown in Fig.9, comparing 2013 and 2001 while the US and China remain the two largest importers in the world, Viet Nam jumps to the fourth largest importer, Turkey enters as tenth, while France and Mexico fall out of the top 10. 
Fig.9: Top 10 Importers of Textiles in 2001 and 2013 (\% share of top 10 total)

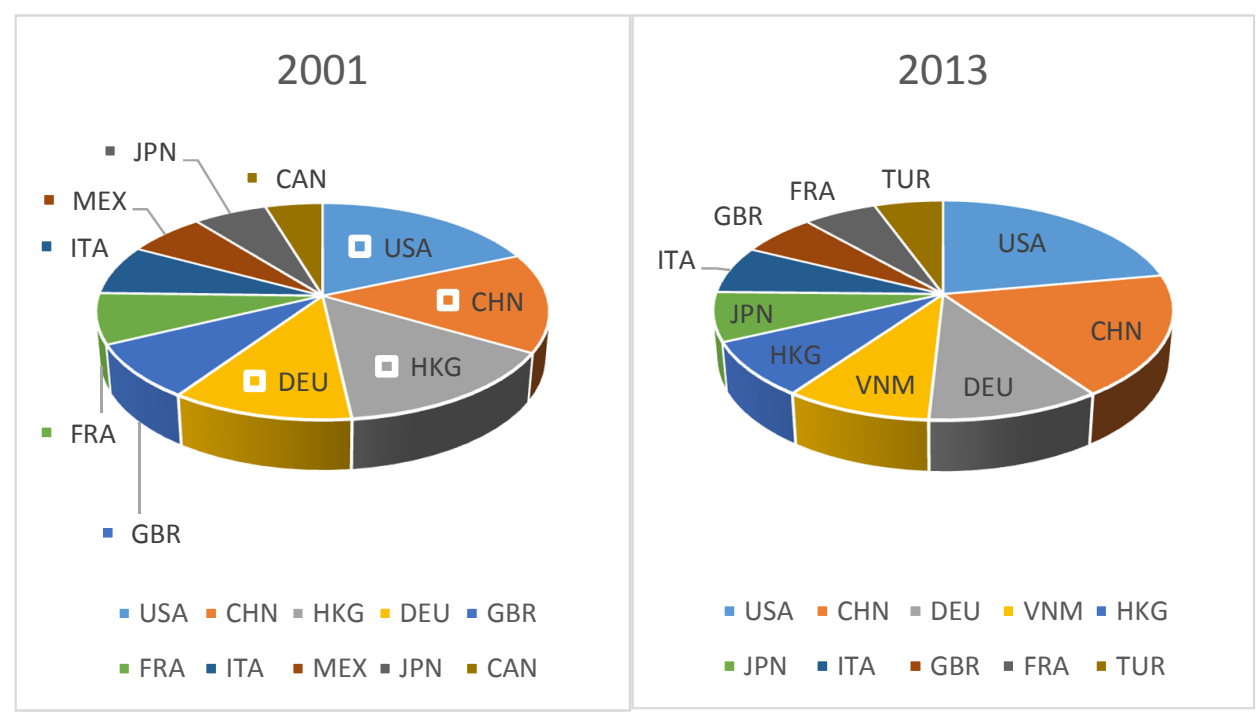

Source: UN's Comtrade Database

The top 10 importers in clothing trade have changed relatively little, as shown in Fig.10. The top 7 does not changed, the United States, Germany, Japan, UK, France, Hong Kong, and Italia, with only Hong Kong falling from fourth in 2001 to sixth in 2013. From the eighth to tenth, Belgium is replaced by Canada, Spain moves forward to eighth, with Netherland remains at ninth. The volume of top 10 importers accounts for about $70 \%$ of world total. 
Fig.10: Top 10 Importers of Clothing in 2001 and 2013(\% share of top 10 total)

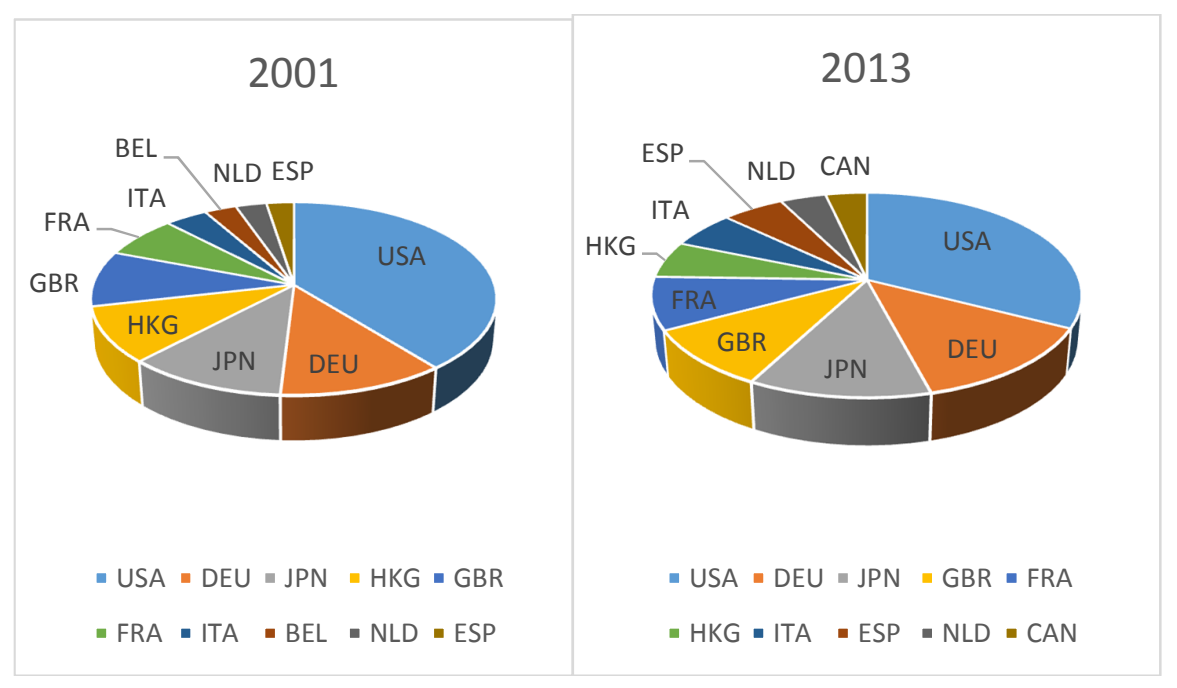

Source: UN's Comtrade Database

Importantly, the import concentration of the largest top 10 and top 5 importers keeps decreasing. As shown in Fig.11, from 2001 to 2013, the top 10 concentration index ${ }^{4}$ of textiles import (textiles10) dropped from 0.56 to 0.50 , and the top 10 concentration index of clothing import (clothing10) dropped more from 0.79 to 0.68 . The falls of the top 5 concentration indices are larger. From 2001 to 2013, the top 5 concentration index for textile imports (textiles5) dropped from 0.38 to 0.34 , and the top 5 concentration index for clothing import (clothing5) dropped more from 0.64 to 0.52 .

\footnotetext{
4 The top 10 concentration index is computed as the share of top 10 importers as a proportion of world imports
} in a particular year, while the top 5 index is the top 5 importers as a share of world. 


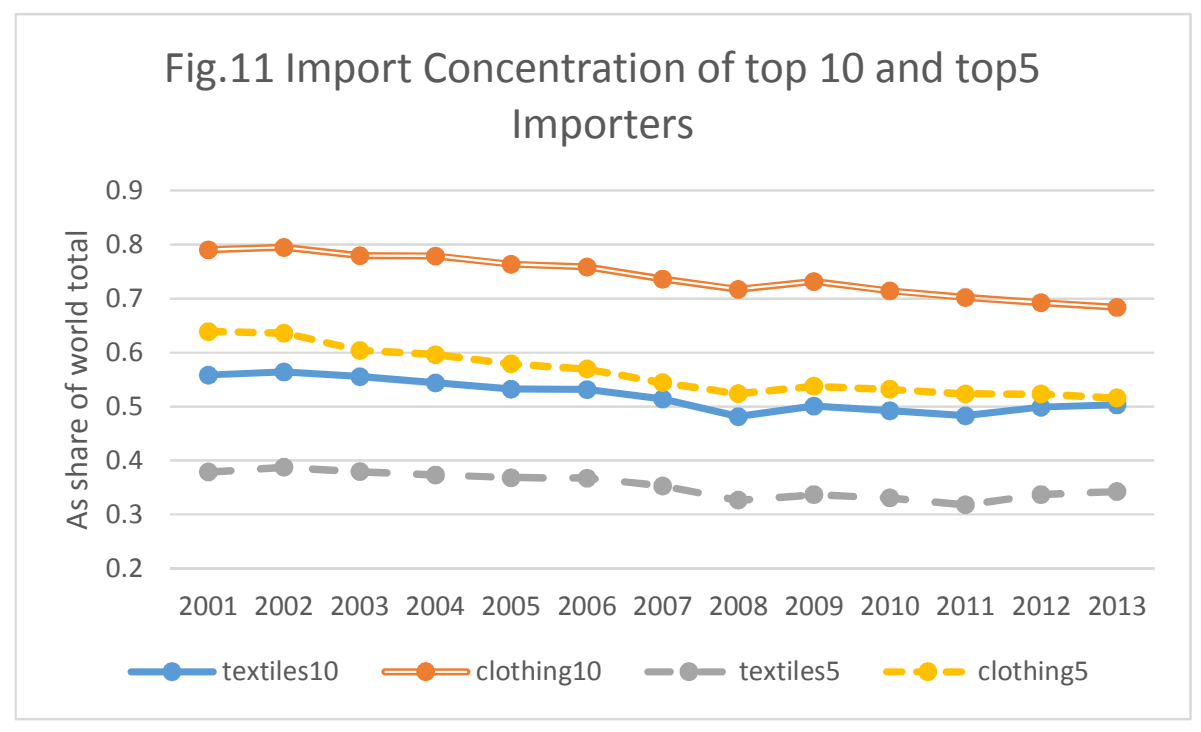

Source: UN's Comtrade Database

The fall in world import concentration means that the import pattern of world textiles and clothing trade had become more diversified by the end of the global quota regime, which can be the result of the improvement of equity in world GDP per capita. Most textile and clothing products belong to a product whose share in consumers' total spending tend to decrease when their income increases. Therefore, the increase speed of developing countries will be higher in textile and clothing imports than the developed countries. Another explanation for such pattern change is the global value chain. This is clear in the curve of textile imports, where the Viet Nam and Turkey entered the top 10 importers as the fourth and tenth largest. Considering their relatively small domestic markets, much of their imports are intermediate products which are re-exported later.

3f) Concentration by country of world exports 
Top 10 Exporters in textiles and clothing have changed more dramatically since 2001 than the top 10 importers, as shown in Fig.12 and Fig.13. In both sectors China remains the largest exporter in the world, and its share increased to nearly half of the top ten exporters' total value. As a share of world exports, China was $11.1 \%$ and $18.4 \%$ in textiles and clothing respectively in 2001, and this has increased to $35.9 \%$ and $40.3 \%$ respectively in 2013. Despite the China containment agreements before 2013, China has acquired advantage in the world exports of textiles and clothing, and the advantage in clothing exports is more obvious.

Fig.12: Top 10 Exporters of Textiles in 2001 and 2013(\% share of top 10 total)

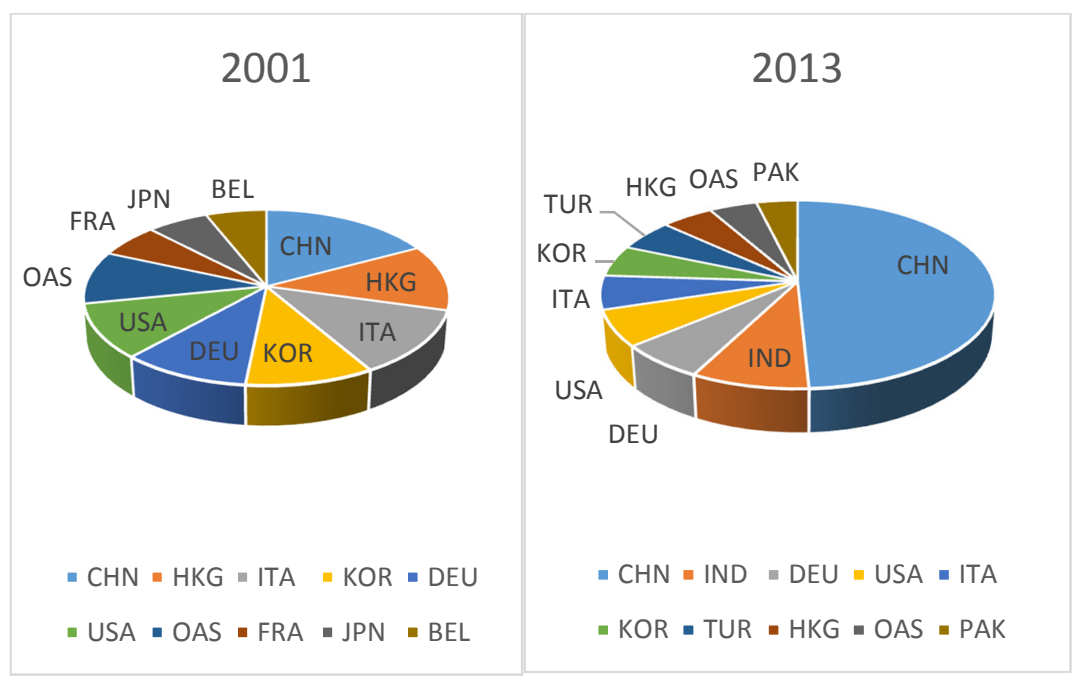

Source: UN's Comtrade Database

As a comparison, Hong Kong, China has fallen behind in this period. Hong Kong, China was the second largest exporters in both sectors in 2001, but in 2013 it was the eighth in textile exporters and the third in clothing exporters. Its share of world 
textiles exports has decreased from $7.8 \%$ in 2001 to $3.6 \%$ in 2013 , while its share of world clothing exports has decreased from $12.0 \%$ to $4.9 \%$ in the same period. A natural explanation for such pattern changes is after the expiration of quota, there is no more need for Chinese exporters to transship their products to Hong Kong, and then export to the final destination of the US, EU and Canada.

Fig.13: Top 10 Exporters of Clothing in 2001 and 2013(\% share of top 10 total)

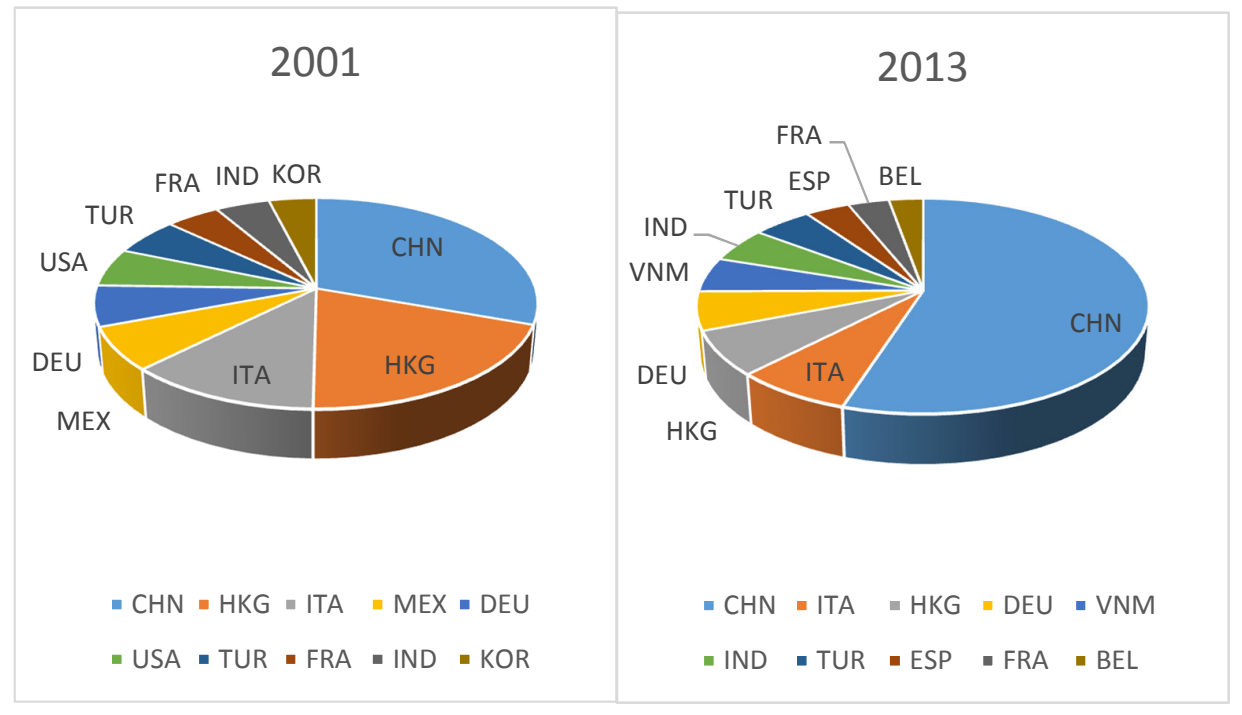

Source: UN's Comtrade Database

In contrast to the import pattern, the export concentration of top exporters keeps increasing. As shown in Fig.14, from 2001 to 2013, the top 10 concentration index ${ }^{5}$ of textiles export (textiles10) increased from 0.65 to 0.73 , and the top 10 concentration index of clothing import (clothing10) increased more from 0.61 to 0.73. The increase of top 5 concentration index are more obvious. From 2001 to

\footnotetext{
5 The top 10 concentration index is computed as the share of top 10 exporters as a proportion of world exports in a particular year, while the top 5 index is the top 5 exporters as a share of world.
} 
2013, the top 5 concentration index of textiles exporters (textiles5) increased from 0.40 to 0.55 , and the top 5 concentration index of clothing exporters (clothing5) increased more from 0.46 to 0.59 . This means that the export pattern of world textiles and clothing trade has been concentrated in a few largest exporters.

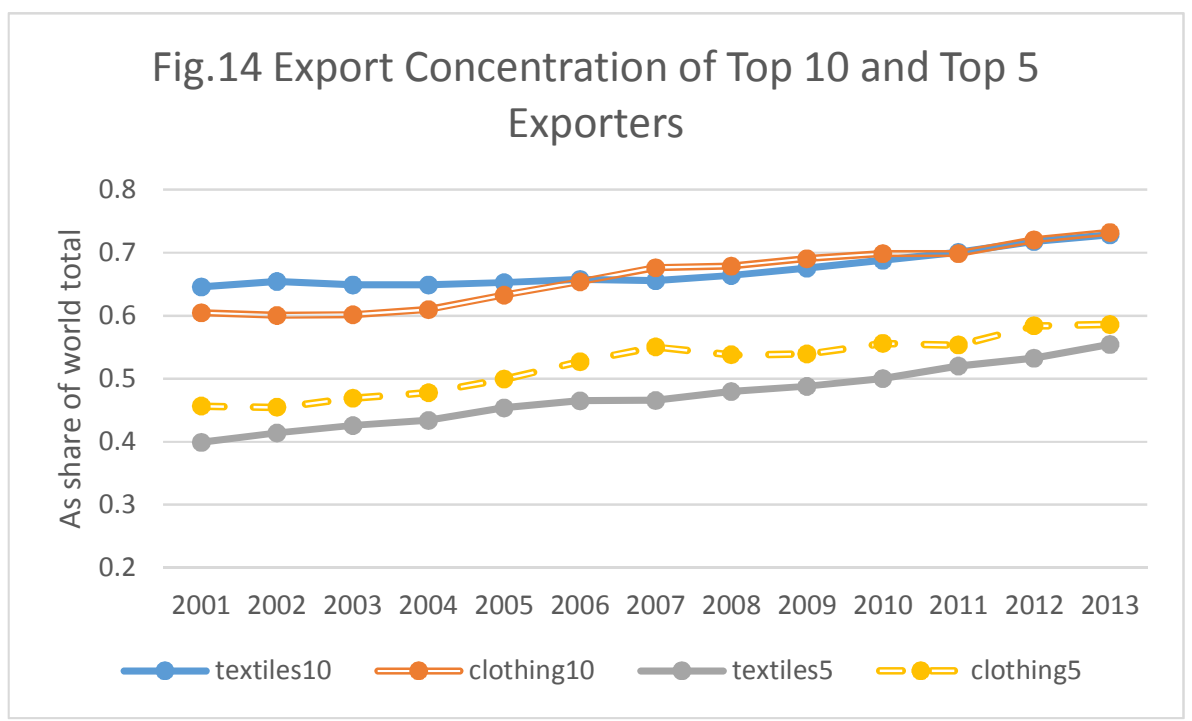

Source: UN's Comtrade Database

Such export pattern changes can be the result of the expiration of quota system. Under the quota system, some potential exporters (e.g. China) cannot obtain enough quota for their products, and this will induce three outcomes. The first is the export volume of China is lower than what it could if there were no quota limitation, and provides market space for other competitive exporters. The second is trans-export through a third economy, for example Hong Kong, China. The last one is the emergence of quota-hopping overseas investment by Chinese companies. With the expiration of quota system, all these three outcomes have changed. China need 
neither trans-export nor quota-hopping invest through a third country, and she could export as much as the importer's domestic market would accept. As shown in Fig.15, China's share of world export increased steadily in both sectors.

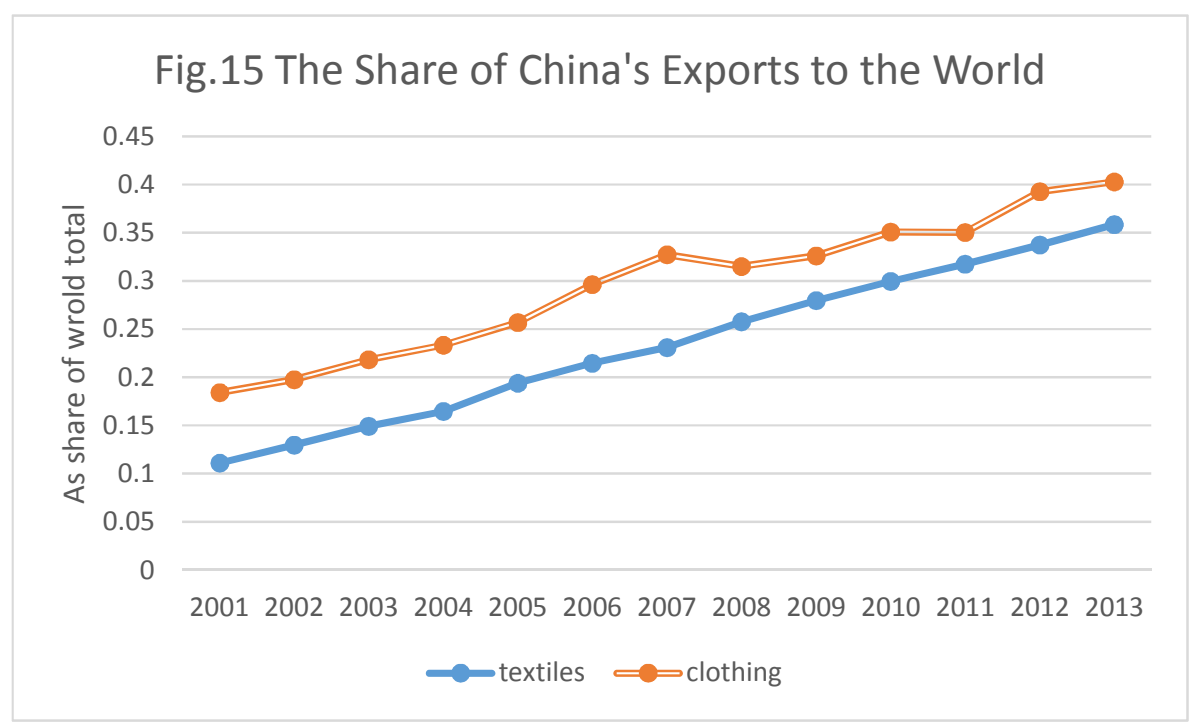

Source: UN's Comtrade Database

\section{Conclusion Remarks}

In his An Inquiry into the Nature and Causes of the Wealth of Nations, Adam Smith provided a famous example in the production of the tools in textiles and clothing sectors: the pin-maker. Adam Smith then suggested that the division of labor is limited by the extent of the market. Two hundred years after that, the obstacles of a global textiles and clothing market were not in technology, but in trade policies. The notorious quota system in the MFA and ATC twisted the global trade patterns in textile and clothing sectors and leaded to the well-being losses of the world as a whole. 
In this paper we discuss the effect of the MFA/ATC after its removal using world trade data and the country data of US. The trade data we analyze are consistent with such theory prediction as more trade volumes, lower product price, smaller effect of RTA, less occasion of transshipment and quota hopping investment, and higher concentration of exporters. We also find the effect on clothing trade is more significant than textiles trade.

\section{Bibliography}

[1]. Dayaratna-Banda, O.G., and John Whalley. (2007). "After the Multi-fiber Arrangement, the China Containment Agreements". Asia-Pacific Trade and Investment Review, 3(1): 28-54.

[2]. Evans, C.L. and Harrigan, J. (2005). "How the MFA Affects Asian Apparel Exports”. In NBER, International Trade in East Asia, NBER-East Asia Seminar on Economics, Volume 14, University of Chicago Press.

[3]. Fasil, C.B., and Borota, T. (2013). "World trade patterns and prices: The role of productivity and quality heterogeneity". Journal of International Economics, 91: $68-81$.

[4]. Khandelwal, A.K., Schott, P.K. and Wei, S-J. (2013). Trade Liberalization and Embedded Institutional Reform: Evidence from Chinese Exporters. American Economic Review, 103(6): 2169-2195.

[5]. Kichko, S., Kokovin S., and Zhelobodko, E. (2014). "Trade patterns and export 
pricing under non-CES preferences". Journal of International Economics 94: 129142.

[6]. Lu, Sheng. (2012). "China takes all? An empirical study on the impacts of quota elimination on world clothing trade from 2000 to 2009”. Journal of Fashion Marketing and Management: An International Journal, 16(3): 306-326.

[7]. Nordas H.K. (2004). "The Global Textile and Clothing Industry post the Agreement on Textiles and Clothing”. The WTO Discussion Papers, no.5.

[8]. Platzer, M.D. (2014). U.S. Textile Manufacturing and the Trans-Pacific Partnership Negotiations. CRS Report, No.42722.

[9]. Trela, I., and Whalley, J. (1995). Internal Quota-Allocation Schemes and the Costs of the MFA. Review of International Economics 3(3), 284-306. 